\title{
The first record of Norellia tipularia (Fabricius, 1794) (Diptera: Scathophagidae) for the fauna of Russia
}

\section{Первая регистраџия вида Norellia tipularia (Fabricius, 1794) (Diptera: Scathophagidae) в фауне России}

\author{
A.L. Ozerov ${ }^{1}$, M.G. Krivosheina ${ }^{2}$ \\ А. $\Lambda$. Озеров ${ }^{1}$, М.Г. Кривошеина ${ }^{2}$
}

\begin{abstract}
'Zoological Museum, Moscow Lomonosov State University, Bol’shaya Nikitskaya 6, Moscow 125009 Russia. E-mail: ozerov2455@rambler.ru 13оологический музей, Московский государственный университет им. М.В. Ломоносова, Большая Никитская ул., 6, Москва 125009 Россия.

${ }^{2}$ A.N. Severtzov Institute of Ecology and Evolution, Russian Academy of Sciences, 119071 Moscow Russia. E-mail: dipteramarina@rambler.ru ${ }^{2}$ Институт проблем экологии и эволюции им. А.Н.Северцова РАН, Ленинский проспект, 33, Москва 119071 Россия.
\end{abstract}

KEYWORDS: Diptera, Scathophagidae, Norellia, Norellia tipularia, fauna, Russia, first record.

КЛЮЧЕВЫЕ СЛОВА: Diptera, Scathophagidae, Norellia, Norellia tipularia, фауна, Россия, первая регистрация.

ABSTRACT. The genus Norellia Robineau-Desvoidy with the species Norellia tipularia (Fabricius, 1794) is recorded from Russia for the first time. Diagnosis for the genus Norellia and the description of Norellia tipularia are given.

РЕЗЮМЕ. Род Norellia Robineau-Desvoidy с видом Norellia tipularia (Fabricius, 1794) впервые отмечен на территории России. Приведены диагноз рода Norellia и описание N. tipularia.

\section{Introduction}

The genus Norellia Robineau-Desvoidy, 1830 at the present time includes 3 species: Norellia tipularia (Fabricius, 1794), Norellia spinipes (Meigen, 1826) and Norellia megistomycta Feng, 2006 [Šifner, 2008].

Some of dipterologists, for example Vockeroth [1965], Gorodkov [1986, 1970], Ozerov [1993, 2008] included the species of the genus Norellisoma Wahlgren, 1917 in this genus also. The differences between the genera Norellia and Norellisoma are the next. In Norellia frons with 1 pair of orbital (or) setae; postocellar setae ( $p o c$ ) absent; scutellum with a pair of strong apical setae, discal scutellar setae absent (Fig. 3); forefemur with one row of long posteroventral $(p v)$ setae only (Fig. 1), row of anteroventral ( $a v)$ setae absent; vein $\mathrm{A}_{1}+\mathrm{CuA}$, not reaching wing margin significantly, female abdominal sternite 8 without spines (Fig. 10). In Norellisoma frons with 2 pairs of orbital (or) setae; postocellar setae ( $p o c$ ) present; scutellum with pair of strong discal setae, apical scutellar setae absent or hair-like (Fig. 4); forefemur with rows of long posteroventral $(p v)$ and anteroventral ( $a v)$ setae (Fig. 2); vein $\mathrm{A}_{1}+\mathrm{CuA}_{2}$ reach- ing wing margin at least as a fold, female abdominal sternite 8 with numerous short spines (Fig. 11).

Norellia tipularia (Fabricius, 1794) and Norellia spinipes (Meigen, 1826) were registered in west Palaearctic. The differences between these two species were discussed by De Jong [1985]. Norellia megistomycta was described from China.

Larvae of the representatives of this genus deve-lop in plants of the family Amaryllidaceae: N. tipula-ria in Leucojum spp., N. spinipes in Narcissus spp. [De Jong, 1985].

None of the species has been registered in the fauna of Russia up to now.

The present publication contains the diagnosis of the genus Norellia and the description of $N$. tipularia, which is registered for the first time for Russia herein from female specimen caught in the neighborhood of Naro-Fominsk (Moscovskaya Oblast'). Illustrations of the structure of male legs and genitalia were made from additional material got from Israel.

\section{Norellia Robineau-Desvoidy, 1830}

Norellia Robineau-Desvoidy, 1830: 673. Gender: feminine. Type-species: Norellia pseudonarcissi Robineau-Desvoidy, 1830: 673, by monotypy [= Cordylura spinipes Meigen, 1826].

Achantholena Rondani, 1856: 101. Gender: feminine. Typespecies: Achantholena maculipennis Rondani, 1856: 101, by original designation [= Cordylura spinipes Meigen, 1826].

DIAGNOSIS. Proepisternum covered with setulae at middle. Postocellar setae ( $p o c)$ absent. Tibia of forelegs of both sexes with row of strong posteroventral setae $(p v)$. Anepisternum covered with setulae usually along dorsal margin and in posterior part only, without setulae posterior to anterior spiracle. Scutellum with one pair of apical setae. 


\section{Taxonomic part}

Norellia tipularia (Fabricius, 1794)

Figs 1, 3, 5-10.

Musca tipularia Fabricius, 1794: 337.

MATERIAL. 1 +, RUSSIA: Moscovskaya Oblast', Ozhigovo $\left(55.453338^{\circ} \mathrm{N}, 36.884709^{\circ} \mathrm{E}\right), 22 . \mathrm{VII} .2010$, D. Gavruyshin (ZMUM).

ADDITIONAL MATERIAL. $2 \sigma^{\top} \sigma^{\top}$, ISRAEL: Mt. Hermon, 1600 m, 2.VII.1986 and 7.VII.1986, A.Freidberg and F. Kaplan; 1 †, Upper Nahal 'Ammud [Upper N. Amud], 28.V.1981, F. Kaplan (TAU).

DESCRIPTION. Male and female. Length of body 7.1-7.8 mm. Length of wing $6.1-6.2 \mathrm{~mm}$.

Head. Frons yellow, with whitish microtrichia along margin of eye. Ocellar triangle blackish. Face, parafacial and gena yellow, with whitish microtrichia. Postcranium black in upper half (with black setae and setulae) and yellowish in lower half (with yellow setae and hairs). 1 orbital, 2-3 frontals, 1 ocellar, 1 inner vertical, 1 outer vertical (approximately 1/3 times as long as inner vertical) setae present; postocellar setae absent; 1 pair of strong vibrissa and 1 pair of short subvibrissa. Antenna yellow. First flagellomere rounded apically, approximately 2.5 times as long as wide. Arista black, sometimes yellow basally, with short rays; longest rays not longer than greatest diameter of arista. Palpus, clypeus and proboscis yellow.

Thorax. Scutum black, grey microtrichose, with yellow median stripe between dorsocentral setae along entire scutum and with lateral yellow stripe posterior to transverse suture; postpronotal lobe yellow in ventral half. Pleura mostly yellow, only anatergite and mediotergite black. Scutum with following black se-tae: 1 notopleural, $0+1$ supra-alars, 1 postalar, and $0+1$ dorsocentral; anterior margin of scutum with a pair of forward directed setae; acrosticals, postpronotals and intra-alar setae absent. Proepisternum with yellow setulae and 1 blackish or yellow seta near ventral margin. Proepimeron with several yellow hairs ventral to spiracle. Anepisternum rarely with hairs in posterior half and 1 seta near posterodorsal corner. Katepisternum with 1 seta in posterodorsal corner. Anepimeron bare. Scutellum with 1 (pair) of strong apical seta.

Legs entirely yellow. Forefemur with row of 6-7 long $p v$, row of 8-10 short $a v$, and usually with 1 apical $p d$ setae. Foretibia with 4 long $p v$ setae, 1 hair-like $d$ and $1 p d$ in basal half, and with 1 hair-like apical $d$. Midfemur with 2-3 thin $a$ in basal half, 3-4 spine-like $p v$ and 5-6 spine-like $a v$ in apical half, and with 1 apical $p d$. Midtibia without striking setae, except $a v$, $p v$ and $d$ apicals. Hindfemur with $1 a d$ in basal half, 2-
3 spine-like $p v$ and 4-5 spine-like $a v$ in apical half, and with 1 apical $a d$. Hindtibia with 2 thin $a d, 1 p d, 1$ preapical $d$, and 1 each of $a d$ and $a v$ apical setae.

Wing tinged with brownish, veins brownish; crossveins $r-m$ and $d m-c u$, veins $\mathrm{R}_{2+3}, \mathrm{R}_{4+5}, \mathrm{M}$ apically darkened. Vein $\mathrm{A}_{1}+\mathrm{CuA}_{2}$ not reaching wing margin. Calypters, including margins, and halteres yello-wish.

Abdomen shining. Tergites 1-5 black in center and yellow laterally, the rest mostly yellow. Synter-gite 1+2 with 1-2 long yellowish setae laterally. Male sternites 4 and 5 as in Figs 7, 8. Epandrium, cerci and surstyli as in Figs 5, 6. End of female abdomen as in Figs. 9, 10; tergite 7 separate dorsally, sternite 8 without spines (Fig. 10).

DISTRIBUTION. France, Germany, Hungary, Italy, former Yugoslavia, Greece and Cyprus [De Jong, 1985], Israel; Russia (Moscovskaya Oblast') — first record.

ACKNOWLEDGEMENTS. We wish to thank Dr. Amnon Freidberg (Tel-Aviv, Israel) for the loan of Norellia tipularia males for study.

\section{References}

Fabricius J.C. 1794. Entomologia systematica emendata et aucta. Secundum classes, ordines, genera, species, adjectis synonimis, locis, observationibus, descriptionibus. Tom 4. C.G. Proft, Fil. et Soc., Hafniae. 434 pp.

Gorodkov K.B. 1970. [Family Scathophagidae (Cordyluridae, Scatomyzidae, Scopeumatidae)] // G.Ya. Bei-Bienko (ed.). Key to the insects of the European part of the USSR. Vol.5. Diptera, Siphonaptera. Part 2. P.440-458 [in Russian].

Jong H., de. 1985. Norellia spinipes (Meigen) in the Netherlands and its distinction from $N$. tipularia (Fabricius) (Diptera: Scathophagidae). // Entomologische Berichten. Vol.45. P.21-23.

Ozerov A.L. 1993. [New Palaearctic species of the genus Norellia (Diptera, Scathophagidae)] // Vestnik zoologii. No.5 . P.67-73 [in Russian].

Ozerov A.L. 2008. Two new species of the genus Norellia Robineau-Desvoidy, 1830 (Diptera, Scathophagidae) from Altay // Far Eastern Entomologist. No.184. P.1-4.

Robineau-Desvoidy J.B. 1830. Essai sur les Myodaires // Mémoires présentés par divers Savans à l'Académie Royale des Sciences de 1'Institut de France. Paris. T.2. P.1-813.

Rondani C. 1856. Dipterologiae Italicae Prodromus. Vol. I. Genera Italica ordinis dipterorum ordinatim disposita et distincta et in familias et stirpes aggregata. Parmae. $228 \mathrm{pp}$.

Šifner F. 2008. A catalogue of the Scathophagidae (Diptera) of the Palaearctic region, with notes on their taxonomy and faunistics // Acta Entomologica Musei Nationalis Pragae. Vol.48. No.1. P.111-196.

Vockeroth J.R. 1965. Subfamily Scatophaginae // A. Stone et al. (eds.). A catalog of the Diptera of America north of Mexico. Unated States Department of Agriculture. Agriculture Handbook. No.276. P.826-842. 
The first record of Norellia tipularia for the fauna of Russia
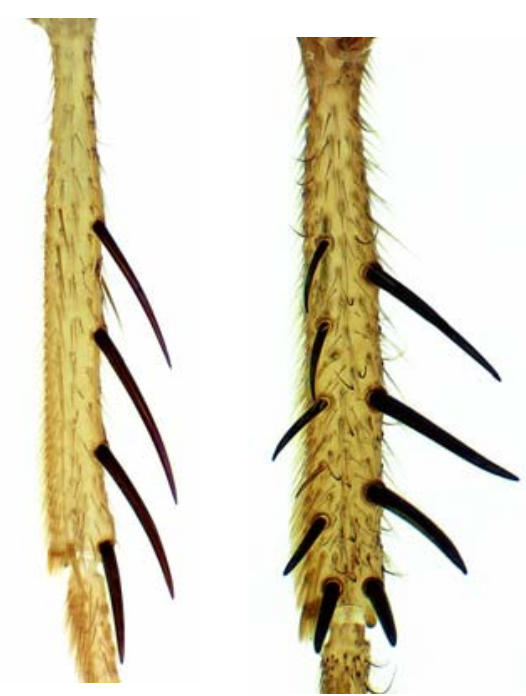

1
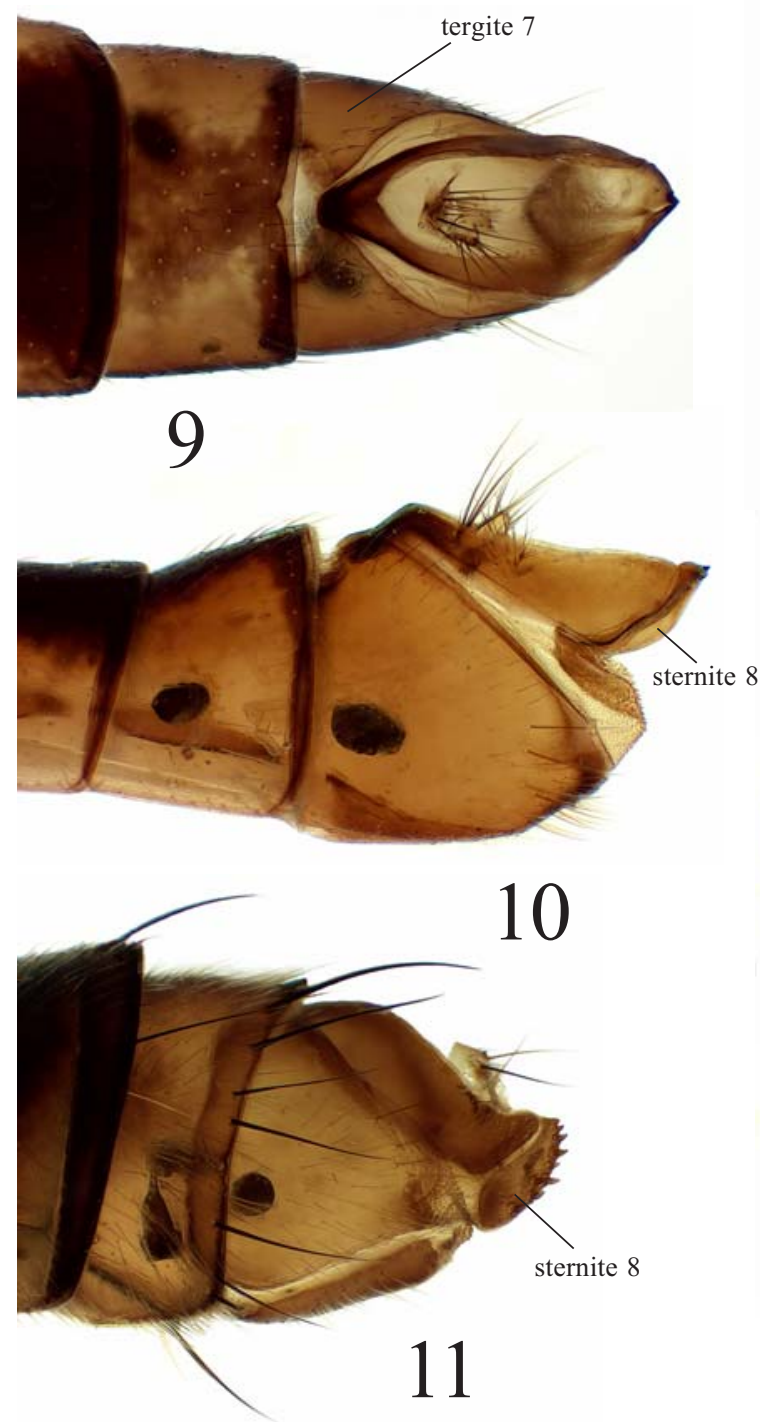

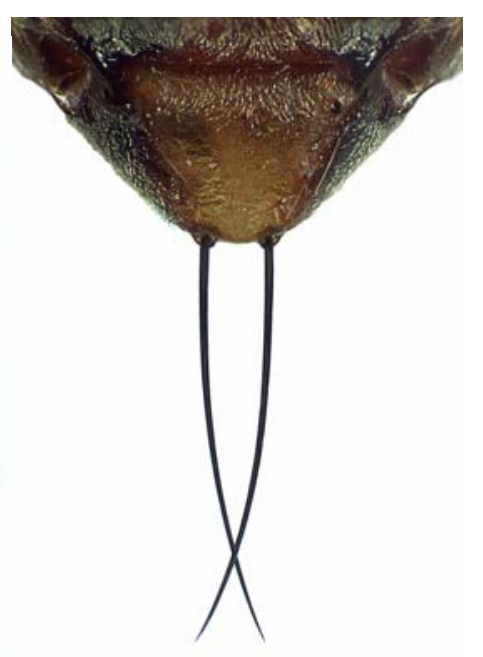

3
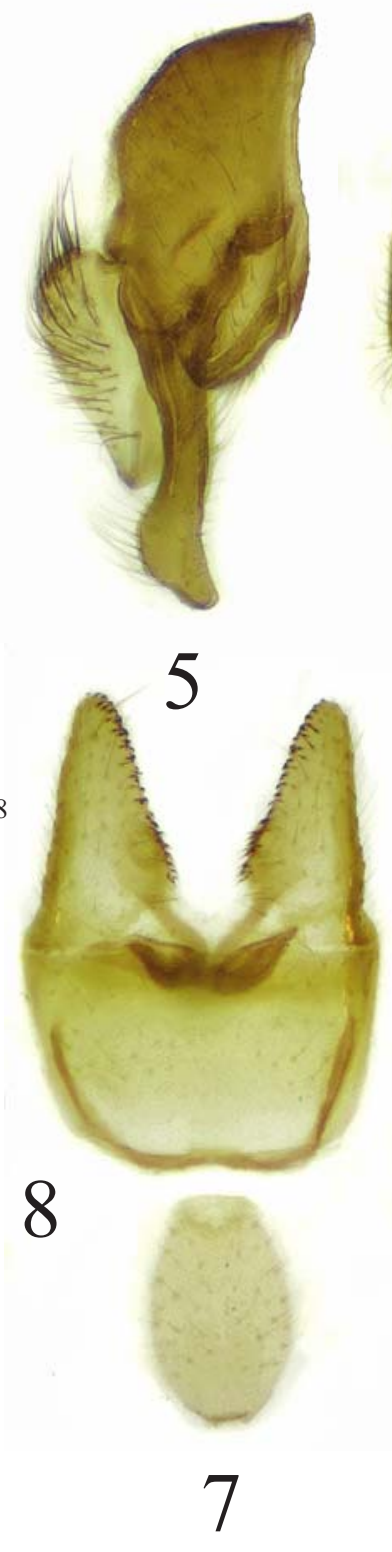
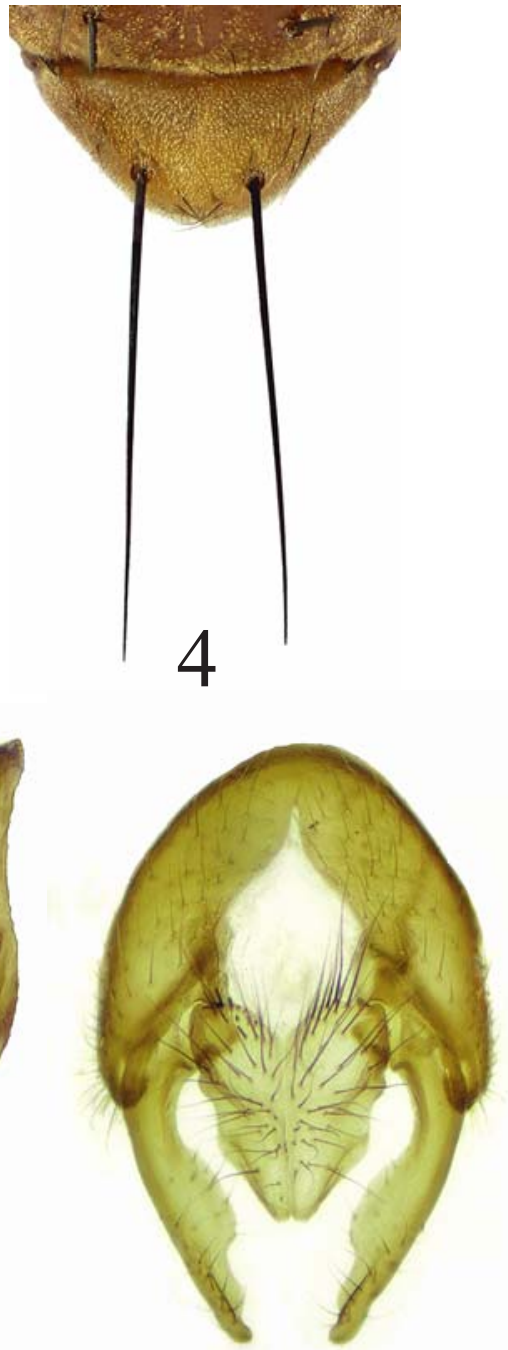

6

Figs 1-11. Norellia tipularia (1, 3, 5-10) and Norellisoma spinimanum $(2,4,11): 1,2$ - fore tibia, ventral view; 3,4 - scutellum; 5 epandrium, cercus and surstylus, lateral view; 6 - same, dorsal view; 7 male sternite $4 ; 8$ - male sternite 5 ; 9 - end of female abdomen, dorsal view; 10,11 - same, lateral view.

Pис. 1-11. Norellia tipularia (1, $3,5-10)$ и Norellisoma spinimanum $(2,4,11): 1,2$ - голень передней ноги, снизу; 3,4 - щиток; 5 эпандрий, церк и сурстиль, сбоку; 6 - то же, сверху; 7 - стернит 4 самца; 8 - стернит 5 самца; 9 концевые сегменты брюшка самки, сверху; 10, 11 - то же, сбоку. 